\title{
The Effect of Social Capital on the Performance of Women Entrepreneurs
}

\author{
Bala Ado Kofar Mata ${ }^{1 *} \quad$ Fatima Ibrahim ${ }^{2}$ \\ Department of Business Administration and Entrepreneurship, Bayero University, Kano P.M.B 3011, Gwarzo \\ Road, Kano State, Nigeria
}

\begin{abstract}
This study investigates the effect of social capital on the performance of women entrepreneurs. Data was collected through a structured questionnaire which was administered on women entrepreneurs. Data was analyzed using Pearson moment correlation and linear regression analyses. Findings revealed a strong and positive relationship between social capital and the performance of women entrepreneurs. Put in another way, every unit or $100 \%$ increase in social capital will lead to an increase of .315 or $31.5 \%$ increase in business performance. This implies that enterprise performance is not restricted to availability of human and financial capital, but the valuable information on markets, suppliers, and methods of operation availed by social capital creates an avenue for improved performance. It was recommended that financial institutions should create avenues through which women would interact and learn diverse business practices.
\end{abstract}

Keywords: Social Capital, Women Entrepreneurs, Performance, Financial Institutions.

DOI: $10.7176 / \mathrm{EJBM} / 12-2-10$

Publication date: January $31^{\text {st }} 2020$

\section{Introduction}

The performance of women entrepreneurs is essential to nations owing to the fact that women enterprises contribute positively to economic development of any country (Ekpe, Mat, \& Ekpe 2015). This can be seen in advances in employment generation, and community development (Kim \& Sherraden, 2014). For instance, it is estimated that small enterprises with full or partial female ownership amount to between $31 \%$ and $38 \%$ ( 8 to 10 million) of formal small enterprises in emerging markets (International Finance Corporation (IFC) \& Mckinsey, 2011). In Louisiana, $51 \%$ of privately owned firms belonged to women which generated over $\$ 13$ billion in sales and employed nearly 102,000 people in 2006 (Mahajar \& Yunus, 2012). In Malaysia, women entrepreneurs contributed $89.5 \%$ to services sector, $7.5 \%$ to manufacturing and $3 \%$ to agriculture in 2005 , with a total of 82,911 business establishments owned by women (SMEs Census: Department of Statistics, 2005). In Nigeria, women agricultural micro-enterprises employed over 60\% of the labor force in the early 1970s (May, 2007). In addition to generating employment, positive outcomes can be seen in community development. Researches (International Labour Organization (ILO) 2009; Lokhande 2003) have shown that whatever profits women get from entrepreneurial engagements, they invest it in their communities through investment in the health, education, and nutrition of their children.

Despite these contributions, evidences from research indicate that the performance of women entrepreneurs is low in comparison to their male counterparts (Akanji 2006). In fact, the magnitude of difference in business outcome is striking. For example, in the United States, only 17.3 percent of women-owned enterprises have annual profits of $\$ 10,000$ or more, compared with 36.4 percent of male-owned firms. Female-owned firms also have lower survival rates than male-owned firms. The average probability of a business closure between 1992 and 1996 is 24.4 percent for female-owned firms, compared with 21.6 percent for male-owned firms (Robert \& Alicia 2009). From this, it can be deduced that women entrepreneurs certainly have deficiencies or obstacles that affect their performance.

Numerous reasons have been presented as causes of this persistent trend of low performance of women entrepreneurs. In some parts of the world, for example in Malaysia, India, and Tanzania, it was discovered that in addition to insufficient funds and training, most entrepreneurs especially women, have poor business performance due to weak social capital (Paul, Hamzah, Samah, Isma'il \& D'Silva 2013; Basargekar, 2011; Kelley, Brush, Greene, \& Litovsky 2010; Tundui \& Tundui, 2013). Given the contributions women enterprises make to economic development, it has been recognized by financial institutions that strategies need to be devised in order to improve the performance of women entrepreneurs in particular, and to develop the field of women entrepreneurship in general.

In view of the foregoing, microfinance institutions, aside the provision of micro credit are designed to make provisions for broad range of services including the creation of platforms for social interaction (Global Entrepreneurship Monitor, 2004). It is expected by these institutions that such initiatives would not only augment the performance of women entrepreneurs, but would also bridge the gap in performance of men and women entrepreneurs.

However, given such innovations by financial institutions, little is known about the effectiveness of social 
capital on the performance of women entrepreneurs. In other words, scanty evidence exists on the ability of these microfinance institutions to achieve the purposes for which they were created. Hence, the objective of this study is to determine the relevance of social capital, in relation to the performance of women entrepreneurs.

\subsection{Statement of the Problem}

The importance of social capital to business success, especially women enterprise performance cannot be overemphasized. A huge number of studies exist in the literature regarding the performance of women enterprises (Shane 2003, Ibru 2009, Ekpe et al 2010, Eunice 2011). However, most of the studies were centered on performance of women entrepreneurs in comparison to their male counterparts.

Studies that have centered on the performance of women entrepreneurs have shown conflicting arguments on how social capital affects performance. In a study conducted in Argentina, it was found that social capital supports business success since social networks constitute new markets. Thus, businesses cannot neglect this kind of capital when acquiring resources to survive and grow (Fornoni, Arribas, \& Vila 2012). Though, this finding is in absolute contrast to an earlier revelation by Nordin, Abdul-hamid, and Woon (2011) where it was discovered that social network does not contribute any significant effect on business performance.

While numerous studies have been conducted on micro finance institutions and performance of women entrepreneurs see for instance (Ibru 2009; Akande 2010; Ekpe et al 2010; Ojo 2009; Casmir 2014), these studies were conducted in the southern part of Nigeria. Considering the diverse nature of women in Kano state, in terms of social, economic, cultural, and educational background, it is unknown whether the findings obtained in other parts of the country would hold for Kano state, as there are no studies conducted in Kano metropolis that would show the effect of social capital on the performance of women entrepreneurs. The main objective of this study is thus, to investigate the effect of social capital on the performance of women entrepreneurs in metropolitan Kano.

\section{Literature Review}

\subsection{Introduction}

This section demonstrates the theoretical background of the study supported by literature. It attempts to identify and highlight the important variables including significant findings from earlier researches which served as the foundation upon which the investigation was laid. Specifically, it highlights the performance of women entrepreneurs and the effect of social capital on such performance as evidenced by literature.

\subsection{Social Capital}

Natukunda (2010) defined social capital as a web of relationships with mutual complementary actions able to harness synergistic potential of members to achieve a common goal. It refers to the quality of human relationships existing within some well-defined social group providing access to network and vital information which has impact on achieving mutual benefits (Basargekar 2011). Similarly, Coleman (1998) viewed social capital as an asset embedded in relationships that facilitate instrumental action among people and the sharing of knowledge and resources from one person to another.

Furthermore, Bourdieu (1985) highlighted three forms of social capital such as bonding social capital which connects individuals to groups and networks, bridging social capital which ties relationships between different socio-economic and ethnic classes, and linking social capital which ties poor people with people occupying important positions in organizations and development committees. In relation to the above definitions, social capital within the framework of this study shall be defined as the social connection from contemporary loan beneficiaries, group membership, and referral programs that is facilitated by the micro finance firms for the benefit of their clients.

\subsection{Theoretical Framework}

\subsubsection{The Weak Tie Theory}

The weak tie theory of (Granovetter 1973), focuses on the strength of the social tie used by a person in the process of job search. Granovetter argued that the closeness and frequency of meetings between members of the same group makes their relationship and ties become strong. Consequently, when one member possesses information, such information disseminates quickly to other members of the group. On the other hand, outside of one's group involves less frequent meetings, and weak relationship and ties. To Granovetter, such weak ties serve as a bridge between strongly interconnected social groups and thus stand as a source for valuable information. The implication of this is that weak ties are more likely to create avenue for opportunities through new information. This is so because with closely knit groups information comes mostly from the same source, and nothing becomes new to the members. Thus, Granovetter in his study found weak ties to be the source of job openings for the interviewed job seekers.

Similarly, it could be argued that women entrepreneur's involvement with other social groups/associations outside of their immediate social groups such as family, friends are more likely to present them with new 
information on markets, suppliers, methods of operation and procedures. Such information, when utilized properly creates valuable opportunities that could alter the growth, profitability, and survival rate of women owned enterprises. These weak ties are gotten from the associations formed in microfinance institutions which are an obligation for securing loan.

\subsection{Social Capital and Performance}

Hamel (1991) observes that firms cannot survive and prosper through their individual efforts as each firm's performance depends on the activities and performance of others. Hence the nature and quality of the direct and indirect relationships that a firm develops with its counterparts is fundamental. Buttery and Buttery (1994) argued that network, when properly utilized can lead to a significant reduction in operation costs and a more efficient customer service. Emmanuel (2006) is of the opinion that social networks once established, are used as a strategic alliance for access to resources, innovation, and social support, which could be in form of Accessibility to new markets, development of more efficient business processes and efficient exchange of information and technology. To give more credence to the above arguments, Guerin (2006) concurred that social capital in the field of entrepreneurship are those resources and social contacts that are embedded in social relationships. He further concluded that when properly exploited, a high level of social capital, built on a favorable reputation, relevant previous experience, and direct personal contact, often assist entrepreneurs to gain access to financial capital, key competitive information sources, potential customers and suppliers. Similarly, Natukunda (2010) submitted that network and group participation can allow members to learn more about themselves and each other thereby enhancing competitiveness in dealing with firms outside the network.

Furthermore, Maurer, Bartsch and Ebers (2011) opined social capital as an integral driver of learning and innovation performance that firms need to adopt for sustainable and successful project output delivery, while Basargekar (2011) submitted that the low rate of default among micro-loan beneficiary is due to the ability of microfinance institutions to employ the use of social capital, peer pressure and monitoring. This is to imply that clients are less willing to employ the tactics of loan default because of their membership of a particular group and the pressure on them to repay by the group. For instance, if micro clients are under pressure for repayment, they are more willing to employ a more judicious and better management of loan given to them which will consequently promote business performance.

Divergently, Bislev (2003) is of the opinion that imposition of group members to foster repayment might make lenders to forego the primary objectives of business expansion, profitability and job creation while focusing more on ensuring repayment. He however recommended that microfinance loan must be accompanied with suitable interest rate and loan repayment period as a means of countering such development. Studies on the effect of social capital on women owned enterprises with regards to performance have generated mixed empirical results across different geographical boundaries. For instance, Morris, Woodworth and Hiatt (2006) conducted a study on a comparative analysis of the financial performance of individual lending and cooperative lending among women entrepreneurs in the Philippines and Bulgaria. In this study, it was discovered that subjects in the cooperative lending group recorded a higher survival rate and better business performance which they concluded was due to a higher level of social capital created by the cooperative organizations. It was clearly demonstrated in the study that the social capital created through social ties and network help the women entrepreneurs to have flexibility in interest payment and repayment schedule, training and skill upgrading, networking with suppliers and customers as well as sharing responsibilities such as child care. Similarly, Woodworth (2008) was able to show a strong connectivity between the success of micro entrepreneurs and development of social capital. He further indicated its inevitability by giving it more importance when compared to access to financial capital. Social capital according to him is an intangible asset that helps micro entrepreneurs in various ways such as leveraging relationships in building customers and suppliers, expanding businesses, reducing stress in times of economic crisis and building commitments towards owned enterprises.

In a cross-sectional study of Natukunda (2010) conducted to examine the effect of credit lending terms and social capital on the performance of women owned enterprises in Uganda, results revealed that a significant and strong positive relationship exists between networking and performance. They therefore recommended that microfinance firms should encourage women to form or join the already existing women associations which can help them to get market information and business ideas in general. Thus, with a favorable lending conditions and the ability of micro finance firms to foster group relationship, it is assumed that micro firms and their clients can benefit from improved performance in key indicators. Another study Basargekar (2011) with an objective of determining the impact of social capital on the social empowerment of Indian women found that a significant difference exists between the mean recorded for pre-membership of micro financial group and post membership after one year. This signifies that the perception of respondents in relation to their level of social empowerment after one year of group association is significantly higher than it was before they joined the micro finance group. In view of these arguments, the following hypothesis has been formulated:

Hi: There is no significant relationship between social capital and performance. 


\section{Methodology}

\subsection{Research Design}

A cross-sectional survey research design was chosen for this study. Based on the review of the literature and the hypotheses that have been formulated, the research design for this study is built around the existence of one independent variable: social capital. The dependent variable, performance of women entrepreneurs is comprised of three indicators: growth, profitability, and survival, presented graphically below in Fig 3.1

Figure 3.1: The hypothesized effect of social capital on the performance of women entrepreneurs.

\section{Independent variable}

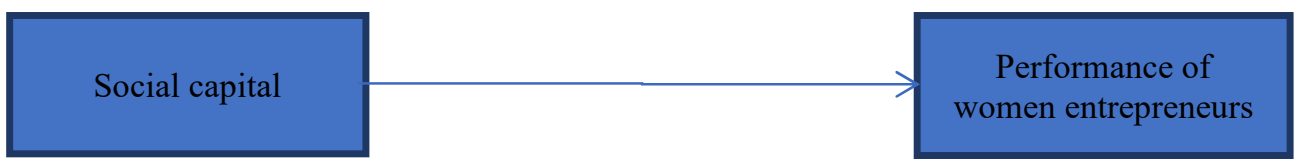

\subsection{Population of the Study}

The population of the study is women clients of Microfinance banks in Kano metropolis who have been registered as clients for three years, specifically from 2012 to 2014. The study focused on two banks: LAPO microfinance bank, and Women Development microfinance bank. The selection was based on the spread of their clients across different locations within the metropolis. As at May 2014, the total number of women entrepreneurs who are clients of LAPO microfinance bank for the past three years is one thousand eight hundred and fifty (1850), while the total number of women clients of women development microfinance bank for the same number of years is one thousand five hundred and fifty (1550). The combined figure for both banks is three thousand four hundred (3400). This combined figure of 3400 forms the population of this study from where the sample was drawn.

\subsection{Measurement of key Variables}

The following independent and dependent variables of the study are measured as follows:-

3.3.1 Social Capital

The eight (8) items used for the measurement of social capital are based on the work of Ritter, Ian and Wesley (2002). These items are designed to measure the extent to which membership of women groups has impacted on the development of client's business enterprise. It also asks questions on the extent to which their fellow entrepreneurs have contributed to their business success through business networking, provision of information on suppliers, markets and new products and services.

\subsubsection{Performance}

Performance was measured on a five point Likert scale which consists of six (6) items adopted from the original work of Rosemond, Alison, and Bernice (2008) in their study on gender, personal values, strategies and small business performance in Ghana, and adapted to suit to the specific need of the current investigation. These items measure performance indices such as growth, in terms of increase in number of employees, increase in working capital, and increase in sales; profitability, in terms of increase in savings; and finally survival, in terms of ability to prevent business loss, and ability to meet business goals and targets.

All the variables used in this study except the socio-economic variables were measured with the aid of a five (5) piont likert rating scale.

\subsection{Sample Size and Sampling Technique}

Given the population for this study, which is three thousand four hundred (3400), a total of three hundred and forty (341) women micro entrepreneurs were selected as the sample size for this study. This sample size is sufficient for adequate representation of the target population going by Krejcie and Morgan (1970) table for sample size determination. Regarding the sampling technique, the multistage sampling technique was used. First, the proportionate sampling technique was adopted in allocating sample size to each of the banks. Secondly, the simple random sampling technique was employed in picking the sample elements from the banks. This was done in order to ensure that all elements are given equal chance of being selected. Below in Table 3.2 is the study population and the basis of selecting sample size from each bank.

Table 3.2: The Population Statistics for the clients of the micro finance banks and the Basis for Sample Selection.

\begin{tabular}{|c|c|c|c|}
\hline Micro finance Bank & $\begin{array}{l}\text { Number } \\
\text { clients }(\mathbf{N})\end{array}$ & $\begin{array}{l}\text { Sample Size Determination /Formula } \\
\text { N/MFB Total population } x 341\end{array}$ & Sample Size \\
\hline LAPO MFB & 1850 & $1850 / 3400 \times 341$ & 186 \\
\hline WOMEN DEV. MFB & 1550 & $1550 / 3400 \times 341$ & 155 \\
\hline
\end{tabular}

\subsection{Instruments for Data Collection}

A multiple choice structured questionnaire was used for data collection. As a means of ensuring that the questions 
are appropriate to the overall objectives of the study, it was divided into two parts.

Section A: consists of nine (9) questions on the following socio-economic variables: Age, Marital status, highest education attained, reason for starting business, years of enterprise existence, type of business involved in, number of current employees, loan size, and tribe. The respondents were asked some specific questions that are close ended and dichotomous in order to generate the data associated with each of the socio-economic variables.

Section B: consists of close ended questions which measure social capital ( 8 items), and performance (6 items).

\subsection{Methods of Data Analysis}

After the completed copies of questionnaire have been retrieved from respondents, they were subjected to editing after which they were serially numbered and numerically coded for processing. In testing the three proposed hypotheses, Pearson moment correlation and simple linear regression techniques were used. The former was employed to test the strength of association among the variables while the later was used to determine the marginal impact contributed by the independent variable: social capital, on the dependent variable, performance of women entrepreneurs. All data processing was carried out with the aid of the statistics for the social sciences (SPSS) version 20.

\section{Result Discussion}

4.1 Features of Respondents

A total of 341 copies of the questionnaire were administered to respondents, however, only 312 copies were returned. From the returned copies, 7 copies were found to be badly filled and incomplete thereby rendering them unusable, leaving the total usable copies to 305 which were consequently employed in statistical analysis indicating a response rate of $89.4 \%$.

\subsection{Demographic Characteristics of the Respondents}

First, the respondents were classified on the basis of marital status. The data revealed that $3.9 \%$ are single, $78.6 \%$ are married, $10.5 \%$ are divorced, and $6.9 \%$ are widowed. They were further classified on the basis of age. It was revealed that $4.9 \%$ are within the age range of 15 and $24,20.4 \%$ are between the ages of 25 and $34,46.4 \%$ fall in the range of 35 and 44 years, $20.7 \%$ are between 45 and 54 years, while $7.6 \%$ are 55 and above.

Regarding the highest educational level attained by them, 167 or $55 \%$ have informal education, 47 or $15.5 \%$ have primary school education, 73 or $24 \%$ have secondary school education, and 17 or $5.6 \%$ are diploma/NCE holders. On the reason for starting the business, 74 or $24.3 \%$ indicated financial independence as their reason for starting, 226 or $74.3 \%$ said they started in order to provide financial support for their family, while 4 or $1.3 \%$ indicated that they started as a result of unemployment. Further, they were asked on the years of their enterprise existence and 46 or $15.1 \%$ said their businesses have existed for a period of $1-3$ years, 61 or $20.1 \%$ indicated a life span within the range of 4-6 years, 25 or $8.2 \%$ have their businesses within the range of 7-9 years while 172 or $56.6 \%$ are business owners of over 10 years old.

Regarding the type of business involved in by them, data revealed that 65 or $21.4 \%$ are engaged in restaurant business, 28 or $9.2 \%$ are involved with agricultural activities, 31 or $10.2 \%$ are fashion designers, 177 or $58.2 \%$ are engaged in petty trading, while 3 or $1 \%$ of the are engaged in other activities. Similarly, they were classified on the basis of number of employees currently employed. Here, 258 or $84.9 \%$ said they have between 1-5 employees, while 46 or $15.1 \%$ have employees between $6-10$. In the same vein 256 or $84.2 \%$ revealed they are Hausa Fulani by tribe, 28 or $9.2 \%$ said they are Yoruba, while 20 or $6.6 \%$ indicated they belong to other tribes.

Finally, on the size of loan given to them, 7 or $2.3 \%$ said they were given less than N20,000 as loan, 99 or $32.6 \%$ said they were given $\mathrm{N} 21,000-\mathrm{N} 40,000,141$ or $46.4 \%$ indicated that they were given between $\mathrm{N} 41,000$ to $\mathrm{N} 60,000,32$ or $10.5 \%$ were given between N61,000 to N80,000, 7 or $2.3 \%$ got between N81,000 and N100,000 while 18 or $5.9 \%$ were given N101,000 and above.

\subsection{Normality Statistics of Major Variables}

According to Cooper and Schindler (2003) normality statistics are those statistics that are used to assess if a distribution of scores is normal and not asymmetric. It is in their opinion that some of the means of testing for normality in a distribution is through the statistics of Skewness and Kurtosis. Below in Table 4.2 is the statistics on Skewness and Kurtosis of the major constructs in this study.

Table 4.2: Normality Statistics of Major Variables

\begin{tabular}{lll}
\hline Statistics & Social Capital & Performance \\
\hline Skewness & -.879 & .837 \\
Kurtosis & .437 & .718 \\
\hline
\end{tabular}

Source: Field Survey, 2015

Norusis (2004) pointed that value of Skewness that is below 2 is deemed appropriate while a Kurtosis value of below 5 can be considered an acceptable level of normality. As revealed by table 4.2 above, almost all the values 
for Skewness and Kurtosis of the constructs under investigation are below the value of one (1) hence an indication of the satisfaction of the assumption of normality to a large extent.

\subsection{Inferential Statistics}

Inferential statistics is used to make judgments of the probability that an observed difference or relationship between groups is a dependable one or one that might have happened by chance. Thus, inferential statistics is employed to make inferences from a data set to a more general condition. Two major inferential statistics are the Pearson product moment correlation and the linear multiple regression and they are the main inferential statistics employed in this study.

4.4.1 Pearson Correlation Analysis

Cooper and Schindler (2003) maintained that Pearson product moment correlation is employed to test the degree of association between two variables. In other words, it is used to examine if an association exists between two variables, and the direction and strength of that association if any. They further contended that a necessary condition for the inclusion of variables in a regression model is the presence of an association between the two variables, as indicated by correlation analysis. Hence to test for the presence or absence of association between the each of the independent variables and dependent variable, a cross correlation of these variables is presented in table 4.3 below.

Table 4.3: Cross Correlation of Major Variables

\begin{tabular}{lll}
\hline & $\mathbf{1}$ & $\mathbf{2}$ \\
\hline Performance of Women Entrepreneurs & 1.0000 & \\
Sig. (2-tailed) & $.358^{* *}$
\end{tabular}

Social Capital

Sig. (2-tailed)

** Correlation is significant at the 0.01 level (2-tailed).

In table 4.3 above, the cross-correlation analysis of the major variable in this study is presented. According to the table, the correlation coefficient between social capital and performance is. $358^{* *} p=0.000(p<0.001)$. Thus, a moderate, highly significant and positive association has been established between the two variables. Specifically, about $12.8 \%$ of the variance in business performance among the women is associated with the variance in the presence of social capital among them. This is to imply that those women who perceive an access to more effective social capital equally tend to report a higher business performance.

Table 4.4 (a) Summary of the Analysis showing the R Square and the Adjusted R Square

\begin{tabular}{llll}
$\mathbf{R}$ & R-Square & Adjusted R-Square & Std Error of the Estimate \\
\hline .408 & .166 & .161 & 2.62275 \\
\hline
\end{tabular}

a. Predictors: (Constant) Social Capital

Table 4.5 (b) Summary of the (ANOVA) Showing the Relationship Between the Independent Variable and the Dependent Variable

\begin{tabular}{llllll}
\hline Model & Sum of Square & Df & Mean Square & F & Sig \\
\hline Regression & 461.795 & 2 & 230.897 & 33.566 & .000 \\
Residual & 2318.158 & 337 & 6.879 & & \\
Total & 2779.953 & 339 & & & \\
\hline
\end{tabular}

Dependent Variable: Performance

Predictors: (Constant) Social Capital

Table 4.6 (c) Results of the Multiple Regression Analysis Showing the Effect of the Predictor Variable: Social Capital on the explained variable: Performance

\begin{tabular}{llllll}
\hline Model Coefficients & Unstandardized & Coefficients Std. Error & Standardized Beta & T & Sig \\
& B & & & & \\
\hline (Constant) & 15.285 & 1.364 & .315 & 11.205 & .000 \\
Social Capital & .207 & .033 & & 6.194 & .000 \\
\hline
\end{tabular}

Dependent Variable: Performance

\subsection{Relationship between Social Capital and Performance}

The hypothesis which states that there is no significant relationship between social capital and performance was tested using simple regression. According to table 4.5 (c) above social capital has a positive and significant impact on Performance at the 0.01 confidence interval with $T$ statistics at $6.194 p=0.000(p<0.01)$. Hence, we can reject this hypothesis. In addition, it has a standardized beta value of .315 indicating that every unit or $100 \%$ increase in social capital among the respondents will lead to a corresponding increase of .315 or $31.5 \%$ in performance of 
women entrepreneurs.

\subsection{Discussion of Findings}

This study hypothesized that there is no significant relationship between micro credit and the performance of women entrepreneurs in Kano metropolis. This hypothesis has been rejected based on the findings that a moderate, highly significant and positive association exists between social capital and performance. This indicates that access to web of relationships that woman entrepreneurs get through micro finance institutions positively affects growth, profitability, and survival of their enterprises. This seems to be in complete agreement with Natukunda (2010) who reasoned that network and group participation can allow members to learn more about themselves and each other thereby enhancing competitiveness in dealing with firms outside the network. Similarly, it empirically agrees with Morris, Woodworth and Hiatt's (2006) discovery among Chilean women who were involved with a cooperative lending group, who had higher level of social capital, created by their cooperative group and those that were not, where the former recorded a higher survival rate and better business performance compared to the latter. Also, it bears semblance with Woodworth (2008) studies where a strong connectivity between the success of micro entrepreneurship and development of social capital was uncovered.

This finding portrays the inevitability of social capital in successful business operations. For instance, the ultimate goal of a business firm is to make a sale of organizational product/services for an exchange of those financial resources which are needed to keep the business afloat. Thus, an access to effective social capital will tend to increase the degree of social interaction, social networking, access to market information, more marketing resources and consequently, more sales. The significant positive relationship between social capital on one hand, and performance on the other supports the central proposition of the weak tie theory, that ties that reach outside of one's social clique are likely to be weak (that is, not emotionally intense, infrequent, and restricted to one narrow type of relationship) rather than strong, and such ties create avenue for valuable information. This result emphasizes the fundamental importance of social capital in improving performance and creating value.

Finally, the R-square value of 0.166 in table 4.5 (a) indicated that about $16.6 \%$ of the variance in performance is being explained by the model.

\section{Summary of Findings and Conclusion}

The study investigates the impact of social capital on performance. Social capital has a beta coefficient of 0.315 indicating that with every unit increase in social capital, a corresponding increase of $31.5 \%$ in performance will ensue. From the findings, it can be deduced that as opposed to conventional thinking, financial capital and human capital are not the only factors that are paramount in increasing the performance of women entrepreneurs as other non-financial factors such as social capital has proven to be significant in affecting performance. This could be attributable to the fact that most of the respondents have low level of literacy as evidenced by the data, $(55 \%$ acquired informal education) thus, they lack basic management skills and knowledge they could have gotten from formal schools, a reason why they found it most valuable when exposed to it through the social groups.

The aim of the study was to contribute to the empirical literature on performance by testing hypothesis formulated from a theoretical perspective. This facilitated a more holistic view of social capital and performance. Based on the findings above, it is concluded that among the women clients of the microfinance banks considered in this study, an increase in access to web of relationships (social capital) will lead to an increase in their performance, and vice versa. Thus, this implies the fundamental importance of social capital as a valuable resource in improving the performance of women entrepreneurs in Kano Metropolis.

Based on the above findings and conclusions arising there from, the following recommendation is put forward. The impact of social capital on performance is significant. Thus, it is recommended that micro finance banks should create a platform where their clients would meet and interact more frequently. This would immensely augment their performance since they would have access to resources they otherwise would not get anywhere.

\section{References}

Akanji, O. O. (2006): The Role of Microfinance in Empowering Women in Africa. Retrieved January 10, 2010, from the African Executive Magazine: http://www.google.com

Basargekar, P. (2010). Measuring Effectiveness of Social Capital in Microfinance: A Case Study of Urban Microfinance Program in India. International Journal of Social Inquiry Volume 3, pp. 25-43.

Bislev, A. (2003). Women's Networks and Microcredit in Yinnan. An Unpublished PhD Dissertation, Department of East Asian Studies, Aarhus University, Denmark.

Bourdieu, P. (1985). The forms of Capital. In J. G. Richardson, Handbook of Theory and Research for the Sociology of the Education. (pp.241-258). Greenwood: New York

Buttery, E. and Buttery A. (1994). Business Networks: Reaching new markets with Low Cost Strategies, Longman Business and Professional, Melbourne: Australia.

Casmir, O.C. (2014) The effect of micro credit on the performance of women entrepreneurs in Delta State, 
International Journal of Empirical Finance, 2(1), 45-51.

Coleman, J. (1998). "Social Capital in the Creation of Human Capital' American Journal of Sociology 94: S95S120.

Cooper, D.R., \& Schindler, P.S. (2003). Business Research Methods. Toronto, Canada. $\quad$ McGraw-Hill/Irwin.

Ekpe, I., Mat, N., and Ekpe, M.I. (2015). Social Networks and Women Micro-Enterprise Performance: A Conceptual Framework Mediterranean Journal of Social Sciences, 6(4), pp.360-366

Ekpe, I., Mat, N.B., \& Razaq, R.C. (2010). The Mediating Effect of Opportunity for Entrepreneurial Activity on Micro-Credit and Women Entrepreneur's Performance: A Conceptual Framework. International Journal of Business and Social Science Vol. 1 No. 3

Emmanuel, K. (2006), Access to Credit, Education and Training, Associations and Networks and Performance of Women Owned Enterprises in Adjumani District

Eunice, A. (2011). The Effect of Micro-Credit Fund Accessibility on the Performance of Women-Owned Businesses. A Research Report Submitted in Partial Fulfillment of the Award of the Degree of Bachelor of Commerce (finance and banking) of Maker ere University.

Fornoni, M., Arribas, I., \& Vila, J.E. (2012) An Entrepreneurs Social Capital and Performance. The role of access to information in the Argentinian case. Discussion papers in economic behavior.

Global Entrepreneurship Monitor (GEM) (2004). Women and Entrepreneurship. Center for Women's Leadership. Banson College, MA, USA.

Granovetter, M. (1973). The Strength of Weak Ties. American Journal of Sociology 78, 1360-1380.

Guérin, I. (2006). Women and Money: Lessons from Senegal, Journal of Development and Change, 37(3), pp. $549-570$.

Hamel, G. (1991). International Strategic Alliances. Strategic Management Journal, Vol 12, issue 12, pp.83-103

Kim, S. M. \& Sherraden, M. (2014). The impact of gender and social networks on microenterprise business performance. Journal of Sociology \& Social Welfar., XLI (3), 49-69

Ibru, C. (2009). Growing Microfinance through New Technologies. Federal University of Technology, Akure, Nigeria.

IFC and Mckinsey Company (2011). Global SME Finance Mapping. [http://www.ifc.org/wps/wcm/connect] site visited on $11 / 10 / 2014$

International Labor Organization (ILO). (2009). Gender Employment. Retrieved July 8, 2009, fromhttp://www.ilo.org

Kelley, D., Brush, C., Greene, P. \& Litovsky, Y. (2010). Global entrepreneurship monitor: 2010 Women's Report. Babson.

Lokhande, M.A. (2003). Micro credit for Women Micro Entrepreneurs. Paper presented at the Welingkar Institute of Management Development and Research, Bangalore, India.

Langowitz, N. \& Minniti, M. (2007). The Entrepreneurial Propensity of Women. Entrepreneurship Theory \& Practice, 31(3): 341-364.

Mahajar, A. J. \& Yunus, J. M. (2012). Factors that encourage women involvement in SMEs in Pahang, Malaysia. The Journal of Human Resource and Adult Learning, 8 (2), 33-41.

Maurer, I., Bartsch, V., \& Ebers, M. (2011). The Value of Intra Organizational Social Capital: How It Fosters Knowledge Transfer, Innovation Performance and Growth. Journal of Organization Studies. 32(2), 157-185.

May, N. (2007). Gender responsive entrepreneurial economy of Nigeria: Enabling women in a disabling environment. Journal of International Women's Studies, 9 (1), 167-175.

Morris, S., Woodworth, W., \& Hiatt, S. (2006). The Value of Networks in Enterprise Development; Case Studies in Eastern Europe and Southeast Asia. Journal of Developmental Entrepreneurship, 11, 4, 345 - 356.

Natukunda, J.H. (2010). Microfinance Credit Lending Terms, Networks and Performance of Women Enterprises: the case of Wakiso district. A dissertation submitted to the school of graduate studies in partial fulfillment of the requirement for the award of the degree of Masters of Business Administration of Makerere University.

Nordin, N. A. M., Abdul-Hamid, A. \& Woon, C. C. (2011). Factors affecting profitability of women entrepreneur's business in Malaysia. Annual Summit on Business and Entrepreneurial Sudies (ASBES 2011), (pp. 972-985). Kuching, Sarawak, Malaysia.

Norusis, M. (2004). SPSS 13.0 Guide to Data Analysis. Upper Saddle-River, N.J.: Prentice Hall, Inc.

Ojo O. (2009): Impact of microfinance on entrepreneurial development: the case of Nigeria Faculty of Administration and Business, University of Bucharest, Romania.

Paul, K. C., Hamzah, A., Samah, B. A., Ismail, I. A. \& D'Silva, J. L. (2013). Value of social network for development of rural Malay herbal entrepreneurship in Malaysia. (p. 4th International Conference on Marketing and Retailing (INCOMaR 2013)). Retrieved from google.com on 1 April 2014: Open Access, doi:10.1016/j.sbspro.2014.04.008.

Ritter T., Ian I. W., Wesley J. J. (2002). Measuring Network Competence: Some International Evidence. Journal of Business and Industrial Marketing Vol. 17 Issue 2/3P. 119-138. MCB UP Ltd 
Robert W. F., \& Alicia, M. R (2009). Gender differences in business performance: evidence from the Characteristics of Business Owners survey. Small Business Economics, 33, pp.375-395

Rosemond B., Alison S., \& Bernice, K. (2008). Gender, Personal Values and Small Business Performance: A Ghanaian Case Study Journal: Journal of Equal Opportunities International Vol. 27. Is. 3 Page 237 -257. Emerald Group Publishing Ltd.

Shane, S. (2003). A General Theory of Entrepreneurship: The individual-opportunity nexus. UK: Edward Elgar.

S.M.Es. Census (2005). Women entrepreneurs: Census of establishments and enterprises 2005. Malaysia: Department of Statistics. Retrieved March 5, 2015 from www.smecorp.gov.my

Tundui, C. \& Tundui, H. (2013). An empirical analysis of social networks and enterprise performance in Tanzania: The case of women owned businesses. International Journal of Developing Societies, 2 (1), 50-60.

Woodworth, W. (2008). Reciprocal Dynamics: Social Capital and Microcredit. ESR Review, Fall, pp.36 - 42. 